\title{
Idrett på glattisen?
}

Idretten har en solside. Prestasjonene, som vi kan lære noe av. Heltene. Den brusende nasjonalfølelsen som vi alle vil ta del i og som nærer vår narsissisme. Idrettens positive effekter på livskvalitet og helse (1). Samtidig har det vært støy rundt skyggesidene.

Én skyggeside, idrettsskadene, har vi taklet godt i Norge. Vi er i front innen forskning på slike skader, etter at vi erkjente at vi ikke klarte å behandle dem godt nok. Man måtte satse mer på dokumentert forebygging (2). Andre skyggesider, som økt risiko for hjertestans og spiseforstyrrelser, har det vært harde debatter om og intern støy og motstand mot å erkjenne, kanskje fordi dette kan oppfattes som uheldig i den gode saks tjeneste - å få folk til å trene og bevege seg mer.

Idretten er i sprik. På den ene side ser man periodevis utmerkede resultater, og stadig mer forskning av høy kvalitet dokumenterer viktigheten av å trene, ikke minst for personer med sykdom. Cardiac Exercise Research Group i Trondheim har i så måte vært fremragende. Pasienter med for eksempel hjertesvikt og kols profitterer på trening (3). Innen kardiologien vet vi nå at langvarig kondisjonstrening fører til økt risiko for atrieflimmer (4), en bivirkning vi trenger å forstå bedre. Man arbeider med å finslipe EKG-kriteriene slik at de kan være et troverdig screeningsinstrument for å forebygge idrettsdødsfallene (5). Resultater fra andre studier kan tyde på at moderat trening er bedre for folkehelsen og livslengden enn hardtrening (6). Den internasjonale bevegelsen Exercise is Medicine (Aktivitetsmedisin) (7) er i gang flere steder i Norge.

På den annen side belaster en annen skyggeside, gjentatte dopinghendelser, idrettens renommé. Dopingreglementet kan synes strengt når slurvete bruk av steroidleppekrem uten antatt prestasjonsfremmende hensikt kan føre til sanksjoner. Vanskeligere er det å forstå rasjonalet bak den omfattende bruken av astmamedisin og de svært høye dosene. Hvem er arkitekten bak dette? Likeledes synes praksisen med å få inhalasjoner av ulik karakter før og mellom renn å være i en gråsone. Grenseoppgangen mellom medikamenter brukt som allment akseptert behandling og medikamenter brukt i prestasjonsfremmende hensikt bør trekkes på ny. Det bør være klarere regler for medikamentdosering og administrasjon.

Det har vært en allmenn oppfatning at vi i Norge ikke har en dopingkultur. Den oppfatningen holder fortsatt for meg. Men den siste tids hendelser har vist at det er flere forhold å rydde opp i også i norsk toppidrett.

Man kan diskutere om skattepenger bør brukes til antidopingarbeid i toppidretten. Andre, inkludert helsevesenet, trenger fellesskapets penger mer. Antidopingarbeidet kan en velstående toppidrett finansiere selv. Den har gjentatte ganger over lang tid korrumpert seg med doping og bør selv ta konsekvensene. Fortsatt doping i toppidretten kan undergrave dens privilegerte posisjon. For å synliggjøre at man virkelig vil dopingen til livs, kunne en andel av premiepengene gå til antidopingarbeid. Doping i breddeidretten er et samfunnsproblem, og samfunnets begrensede midler burde kanskje i større grad brukes der.

Flere idrettsmedisinske kolleger har måtte gå av i kjølvannet av dopingsakene. Tradisjonelt har idrettsmedisinere vært spesialister i ortopedi, i fysikalsk medisin eller i allmennmedisin. Bør idrettsmedisinen være flinkere til å bruke flere fagspesifikke spesialister $i$ annenlinjetjenesten, også på grunn av den rivende fagutviklingen i ulike subspesialiteter? Lungemedisinere, gastroenterologer og kardiologer har vært for fraværende, og flere fag, for eksempel infeksjonsmedisin, hvis pasientgruppe utgjør en stor andel av toppidrettsmedisinen (8), burde være representert.

Idretten representerer store verdier. Feil i toppidretten har store konsekvenser og får raskt medienes søkelys på seg. System-, risikoog kvalitetsanalyser er selvfølgelig i andre bransjer. Man bør se nøyere på organiseringen av idrettsmedisinen - på bruk av spesialister, ansvar og rettigheter for idrettsleger og registrering av reseptforskrivning - for å få et transparent og etterprøvbart system. Idrettens skyggesider bør diskuteres åpent - idretten blir ikke mindre attraktiv av den grunn.

Erik Ekker Solberg

erik.solberg@diakonsyk.no

Erik Ekker Solberg (f. 1952) er dr.med., spesialist i indremedisin og i hjertesykdommer og autorisert idrettsmedisiner. Han er overlege ved Diakonhjemmet Sykehus og leder seksjonen for sportskardiologi i European Society of Cardiology og arbeidsgruppen for preventiv kardiologi i Norsk Cardiologisk Selskap.

Forfatter har fylt ut ICMJE-skjemaet og oppgir ingen interessekonflikter.

\section{Litteratur}

1. Pedersen BK, Saltin B. Exercise as medicine - evidence for prescribing exercise as therapy in 26 different chronic diseases. Scand J Med Sci Sports 2015; 25 (suppl 3): 1-72.

2. Oslo Sports Trauma Research Center. www.ostrc.no (24.11.2016)

3. Forskning ved CERG. www.ntnu.no/cerg/forskning (24.11.2016).

4. Myrstad M, Nystad W, Graff-Iversen S et al. Effect of years of endurance exercise on risk of atrial fibrillation and atrial flutter. Am J Cardiol 2014; 114: 1229-33.

5. Drezner JA, Ackerman MJ, Anderson J et al. Electrocardiographic interpretation in athletes: the 'Seattle criteria'. Br J Sports Med 2013; 47: 122-4.

6. Eijsvogels TM, Thompson PD. Exercise Is Medicine: At Any Dose? JAMA 2015: 314: 1915-6

7. Exercise is Medicine. www.exerciseismedicine.org (24.11.2016)

8. Hanstad DV, Engebretsen L. Sykdom i OL-troppen i Torino 2006. Tidsskr Nor Lægeforen 2007: 127: 614-6. 